\title{
Advances in Materials
}

\section{Potential Use of Sewage Sludge Ash in Lime-Based Materials}

\author{
Mamoudou Sall, ${ }^{1,}$, Alassane Traoré2, Abdou Ciss Wade ${ }^{1}$, Prince Momar Gueye ${ }^{3}$, Saliou Diouf ${ }^{1}$, \\ Gora Dieye $^{1}$, Djibril Diop ${ }^{1}$ \\ ${ }^{1}$ Laboratory of X-ray, Department of Physic, Faculty of Sciences and Techniques, University of Cheikh Anta Diop, Dakar, Senegal \\ ${ }^{2}$ Institute of Applied Nuclear Technology, Department of Physics, Faculty of Sciences and Techniques, University of Cheikh Anta Diop, \\ Dakar, Senegal \\ ${ }^{3}$ Laboratory of Civil Engineering Materials, High Polytechnic School, University of Cheikh Anta Diop, Dakar, Senegal
}

\section{Email address:}

basall13@yahoo.fr (M. Sall)

*Corresponding author

\section{To cite this article:}

Mamoudou Sall, Alassane Traoré, Abdou Ciss Wade, Prince Momar Gueye, Saliou Diouf, Gora Dieye, Djibril Diop. Potential Use of Sewage Sludge Ash in Lime-Based Materials. Advances in Materials. Vol. 10, No. 2, 2021, pp. 12-22. doi: 10.11648/j.am.20211002.11

Received: May 19, 2021; Accepted: June 3, 2021; Published: June 15, 2021

\begin{abstract}
Recycling of wastes and their by-products is attracting increasing interest worldwide because of the high environmental impact in the cement, concrete and other industries. This work deals with the study of the physico-chemical characteristics of binders based on sewage sludge ashes and lime. In a first step, we used X-ray fluorescence to determine the chemical composition of ash, lime and binders. This allowed us to see that the chemical composition of sewage sludge ash is similar to that of cement. We then used X-ray diffraction to identify the main mineralogical phases in the samples. Compressive strengths of mortars containing $20 \%, 40 \%, 60 \%$ and $80 \%$ of SSA showed that SSA has a long-term positive effect which might be related to a slight pozzolanic activity. The $\mathrm{L}_{4}$ binder consisting of $80 \%$ fine ash and $20 \%$ lime has a higher compressive strength than the others. The binder setting start time is greater than that of cement but shorter than that of lime. The study of the thermophysical properties of the $\mathrm{L}_{4}$ binder shows that it has a higher thermal resistance than cement and clay mortars. Moreover, it heats up less quickly because of its low effusivity compared to the latter two. This analysis highlighted the principal characteristics that must be taken into account to use SSA correctly in lime-based materials.
\end{abstract}

Keywords: Sewage Sludge Ash, Lime, Binder, X-ray Fluorescence, X-ray Diffraction, Thermomechanical Behavior

\section{Introduction}

Sludge ash is very interesting for many applications because it can be mixed with cement or binders such as lime to give rise to new materials with several attractive physical characteristics such as the increase in resilience, the longterm strength of mortars [1-3]. Their mechanical properties open industrial perspectives for the manufacture of cement and building at lower cost with some ecological contribution. In fact, new environmental challenges and research opportunities arise on the use of these solid wastes as well as their basic properties. Recycling of these wastes and their byproducts is attracting increasing interest worldwide because of the high environmental impact in the cement, concrete and other industries. For example, lightweight concrete can be made from industrial by-products and hazardous solid wastes such as fly ash, sewage sludge ash, bottom ash, slag, etc. Cement can be replaced by 15 to $35 \%$ by this waste without significantly affecting the properties of the material obtained [4]. In some studies, replacing cement with $10 \%$ or $20 \%$ ash from sewage sludge shows an increase in setting time due to the significant presence of phosphorus in sludge ash [5]. Similarly, the compressive strength of the mortars was lower than that of the reference mortar consisting solely of cement [6]. In fact, the addition of these ashes slows down the kinetics of resistance development; however, the long-term strength of the mortar with addition was greater than that of the reference mortar [5]. In the literature, it is reported that these additions can improve sulphate concrete's strength, workability, and also decrease permeability [4]. It has been 
observed that the characteristics of ash from sewage sludge are similar to those of ceramics. Their use in ceramics applications for bricks, tiles and ceramic glass considerably improves these materials by densifying them, increasing their strengths [7]. Ceramic panes with ash additions have achieved higher resistances than natural materials such as granite and marble with strong durability properties [8].

The strength activity index (SAI) value of SSA was smaller than that of fly ash; the effectiveness of using SSA in mortar was lesser than that of fly ash [9]. Moreover, the water demand of SSA mortar is higher than that of ordinary cement mortar. S. Pan found that the addition of SSA affected the mortar workability [10]. This phenomenon is primarily due to the porous and irregular morphology of SSA. Consequently, it is difficult to adequately maintain water-to-cement ratio and workability of SSA mortar simultaneously. The application of mechanical grinding to adjust SSA fineness was an effective modification to improve SSA mortar properties [3]. Regarding the problems related to the cost of construction in the building, air pollution such as greenhouse gases and energy expenditure for the production of cement, we propose to study the effect of the integration of the ashes of Sewage treatment plant (STEP) in lime, to produce an environmentally-friendly cement. Indeed, lime can react with silica in the presence of water to produce a hydrated calcium silicate responsible for the resistance of cementitious materials. Since wastewater treatment plants produce large amounts of solid waste such as STEP ashes, they can be recovered and be used as building materials [4-6, $11]$.

This work deals with the study of the physico-chemical characteristics of binders based on sewage sludge ashes and lime. In a first step, we used X-ray fluorescence to determine the chemical composition of ashes, lime and binders. X-ray fluorescence is also used in ash characterization, analysis of environmental samples, including industrial sites soils to study their contamination by heavy metal [12-15].

Following the X-ray fluorescence of the samples, we studied their mineralogical behavior.

We then used X-ray diffraction to identify the main mineralogical phases present in the samples.

Compressive strength of samples based on sewage sludge ash and lime are also investigated in this study.

The thermal conductivity and effusivity of samples were determined simultaneously using a transient method.

This analysis highlighted the principal characteristics that must betaken into account to use SSA correctly in lime-based materials.

\section{Materials and Methods}

\subsection{Origin of Ash}

The sewage sludge ash used in this work come from the Senegalese sewage treatment plant of Camberene located in the Dakar region. The sludge is dewatered, dried and burnt in a fluidized bed incinerator at $850^{\circ} \mathrm{C}$. The sewage sludge ash has a gray color, is entrained by the combustion gases and is recovered during the purification (Figure 1).

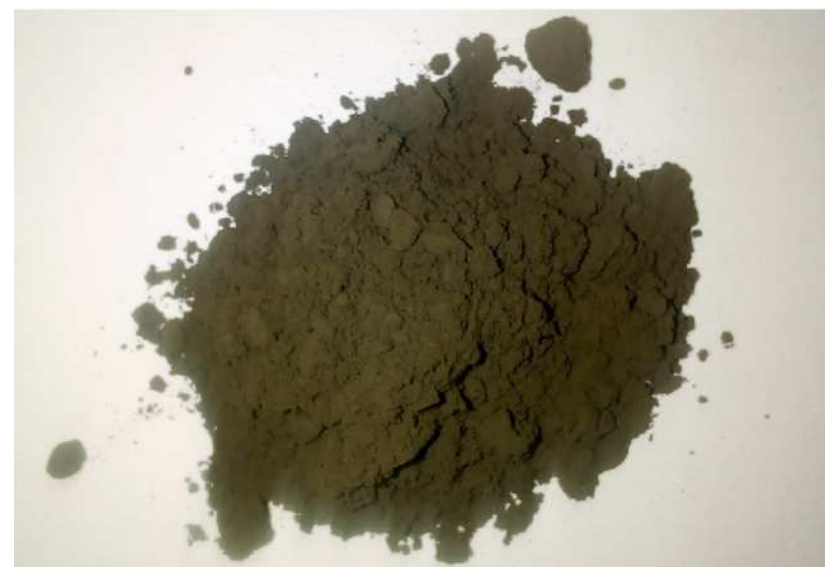

Figure 1. Sewage sludge ash.

It has an apparent density of $0.71 \mathrm{~g} / \mathrm{cm}^{3}$ and an absolute density of $2.4 \mathrm{~g} / \mathrm{cm}^{3}$.

The lime, as an important material used in the building construction, has an apparent density varying between 0.6 and $0.75 \mathrm{~g} / \mathrm{cm}^{3}$ while its absolute density is in the range of 2.6 and $2.9 \mathrm{~g} / \mathrm{cm}^{3}$.

\subsection{Experimental Methods}

The experimental methods used for the physical and chemical characterization of ashes are shown in Table 1:

Table 1. Experimental methods for the physical and chemical characterization of SSA, and for the study of the activity of SSA in lime-based materials.

\begin{tabular}{|c|c|}
\hline & X-ray fluorescence (XRF) \\
\hline Chemical analysis & $\begin{array}{l}\text { X-ray portable fluorescence Niton XLT900s (P-XRF) for our X-ray analyzes with a measurement time of } 350 \mathrm{~s} \text {. } \\
\text { XRF was performed with } 100 \% \text { normalization and full fundamental parameter quantification techniques }\end{array}$ \\
\hline Mineralogy & $\begin{array}{l}\text { X-ray diffraction }(\mathrm{XRD}) ; \mathrm{Cu} \mathrm{K} \alpha \text { radiation }(\lambda=1.54060 \AA) 2 \theta \text { step interval of } 0.04^{\circ}\left(10^{\circ}-70^{\circ}\right) \text { and acquisition time } \\
\text { of } 1560 \mathrm{~s}\end{array}$ \\
\hline Effect on binder hydration: & -XRD of mixtures lime-ash-water \\
\hline Mineralogical study Setting time & - Setting time using Vicat apparatus (NF EN 196-3) \\
\hline Effect on mechanicalproperties of & Compressive strength of $4 \times 4 \times 16 \mathrm{~cm}$ prisms (NF EN 196-1) \\
\hline $\begin{array}{l}\text { Effect on thermal properties of } \\
\text { mortars }\end{array}$ & $\begin{array}{l}\text { The thermal test samples were also prepared in a mould of dimensions } 10 \mathrm{~cm} \times 10 \mathrm{~cm} \times 2 \mathrm{~cm} \text {. All thermophysical } \\
\text { experiments were performed using samples prepared in a mould of dimensions of } 10 \mathrm{~cm} \times 10 \mathrm{~cm} \times 2 \mathrm{~cm} \text {. The thermal } \\
\text { conductivity and effusivity of samples were determined simultaneously using a transient method [16] }\end{array}$ \\
\hline
\end{tabular}


For the Thermal test, the hot plate transient method was used in an asymmetrical configuration to determine simultaneously the thermal conductivity and effusivity of samples [16, 17]. The different elements that make up the experimental device are represented in Figure 2.

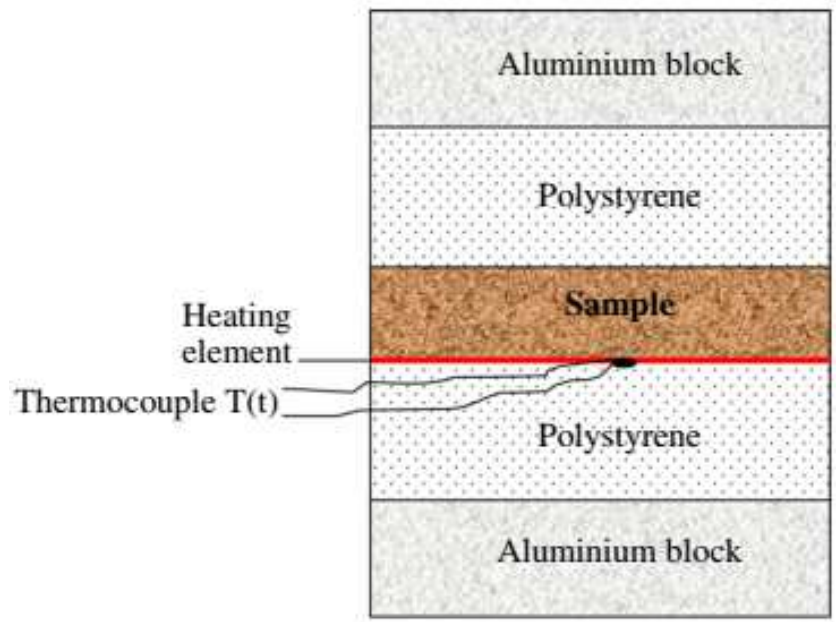

Figure 2. Schema of the experimental hot plate device.

This method was then used in an asymmetrical configuration. It consists in embedding a heating element on which a thermocouple wasfixed, between the materialto be characterized and a $5 \mathrm{~cm}$ thick polystyrene plate.

Since the thermocouple is in contact with polystyrene that is a deformable material, the presence of the thermocouple does not increase the thermal contact resistance between the heating element and the polystyrene. Furthermore, since polystyrene is an insulating material, this thermal contact resistance will be neglected.

The whole set was put between two aluminum blocks with a thickness of $4 \mathrm{~cm}$. A flux step is sent in the heating element and the temperatures $\mathrm{Ts}(\mathrm{t})$ at the center of the heating element is recorded. The processing of the recording of Ts $(t)$ is realized by supposing that the heat transfer at the center of the heating element is $1 \mathrm{D}$. The temperature at the level of the aluminum block is constant.

\section{Results and Discussion}

\subsection{X ray Fluorescence Analysis}

A portable XRF device Niton XLT900s was used to analyze the chemical composition of the sludge ash in terms of major and minor elements (Table 2). Oxides are the major elements and are expressed in $\%$, while the minor elements are given in $\mathrm{mg} / \mathrm{kg}$.

Table 2. Results of major (\%) and minor $(\mathrm{mg} / \mathrm{kg})$ elements using XRF technique of sewage sludge ash contents.

\begin{tabular}{ll}
\hline Elements & Sewage sludge ash \\
\hline $\mathrm{SiO}_{2}$ & 24.1 \\
$\mathrm{Al}_{2} \mathrm{O}_{3}$ & 6.69 \\
$\mathrm{Fe}_{2} \mathrm{O}_{3}$ & 12.6 \\
$\mathrm{CaO}$ & 22.2 \\
$\mathrm{MgO}$ & 3.90 \\
$\mathrm{~K} 2 \mathrm{O}$ & 3.22 \\
$\mathrm{TiO}$ & 0.66 \\
$\mathrm{MnO}$ & 0.10 \\
$\mathrm{P}_{2} \mathrm{O}_{5}$ & 5.92 \\
$\mathrm{~Pb}$ & 357 \\
$\mathrm{Cu}$ & 1264 \\
$\mathrm{Cr}$ & 212 \\
$\mathrm{Zn}$ & 3632 \\
$\mathrm{As}$ & 16 \\
\hline
\end{tabular}

The chemical composition shows that SSA is mainly of silicon, calcium, iron, aluminum and phosphorus. The amount of $\mathrm{CaO}$ and $\mathrm{P}_{2} \mathrm{O}_{5}$ is high compared to classical mineral admixtures such as fly ash, silica fume or metakaolin [18-20].

In Table 3 we resume studies from other authors in order to give a comparative asset in term of elemental composition with the samples we have used.

Table 3. Comparison of major (\%) and minor ( $\mathrm{mg} / \mathrm{kg}$ ) element contents measured with other authors working with the same materials.

\begin{tabular}{llllll}
\hline Element & Sewage sludge ash PW & (Martin Cyr, 2007) & (NuriaHusillos Rodríguez, 2013 & L. C Morais (2010) & Siew Choo Chin (2016) \\
\hline $\mathrm{SiO}_{2}$ & 24.1 & 34.2 & 3.72 & 26.39 & 18.49 \\
$\mathrm{Al}_{2} \mathrm{O}_{3}$ & 6.69 & 12.6 & 2.56 & 12.16 & 7.95 \\
$\mathrm{Fe}_{2} \mathrm{O}_{3}$ & 12.6 & 4.7 & 7.58 & 5.92 & 14.44 \\
$\mathrm{CaO}$ & 22.2 & 20.6 & 7.62 & 23.25 & 4.20 \\
$\mathrm{MgO}$ & 3.90 & 1.9 & 0.60 & 14.11 & 0.91 \\
$\mathrm{~K}_{2} \mathrm{O}$ & 3.22 & 1.7 & 0.53 & 1.32 & 1.13 \\
$\mathrm{TiO}_{2}$ & 0.66 & 0.9 & 0.23 & 0.81 & 0.99 \\
$\mathrm{MnO}$ & 0.10 & 0.06 & 0.05 & 0.11 & 0.09 \\
$\mathrm{P}_{2} \mathrm{O}_{5}$ & 5.92 & 14.8 & 6.43 & 8.44 & 6.56 \\
$\mathrm{~Pb}$ & 357 & 720 & 40 & - & 30 \\
$\mathrm{Cu}$ & 1264 & 2483 & 320 & - & 130 \\
$\mathrm{Cr}$ & 212 & 2636 & 1270 & - & 20 \\
$\mathrm{Zn}$ & 3632 & 7103 & 1020 & - & 810 \\
$\mathrm{As}$ & 16 & 23 & 5.8 & - & - \\
\hline
\end{tabular}


The high variability between values shows that sludge ashes depend on several parameters: sludge composition, treatment conditions such as incineration temperature and additives.

The sum of $\mathrm{SiO}_{2}, \mathrm{Al}_{2} \mathrm{O}_{3}$ and $\mathrm{Fe}_{2} \mathrm{O}_{3}$ represent less than $70 \%$ of SSA. It was known that these oxides compose the reactive part of pozzolanic materials but there are significantly lower in SSA than in other classical mineral admixtures [18-19].

The minor elements are much less representative in our ashes when compared with those in Cyr's work [6]. However the concentration of $\mathrm{SiO}_{2}, \mathrm{Al}_{2} \mathrm{O}_{3}$ and $\mathrm{Fe}_{2} \mathrm{O}_{3}$ are similar to both sewage sludge ash used in the present work and sewage sludge ash in ref. [21] of Siew Choo Chin. The concentration of $\mathrm{CaO}$ in the former is instead four times higher than that in the latter. The similarity of these ashes with ours is important to highlight as they are both used in the processing of cement and concrete. Indeed, our ashes show some similarities with one type of cement in Senegal having the following chemical composition: $\mathrm{SiO}_{2}$ (19.53), $\mathrm{Al}_{2} \mathrm{O}_{3}$ (7.12), $\mathrm{Fe}_{2} \mathrm{O}_{3}(2.22), \mathrm{CaO}$ (65.5). This suggests that the sewage sludge ashes presented in this work may be used in civil engineering [22].

In order to assess the hydraulic and pozzolanic activity of SSA, several mixtures: SSA with water and SSA with lime and water were prepared and analysed using XRD and mechanical behavior (Table 4).
Table 4. Sewage sludge ash and lime at different proportion.

\begin{tabular}{ll}
\hline Mix combinations & Designation \\
\hline $20 w t \%$ Sewage sludge ash $+80 w t \%$ lime & L1 \\
$40 w t \%$ Sewage sludge ash $+60 w t \%$ de lime & L2 \\
$60 w t \%$ Sewage sludge ash $+40 w t \%$ de lime & L3 \\
$80 w t \%$ Sewagesludge ash $+20 w t \%$ de lime & L4 \\
$100 w t \%$ Sewage sludge ash (cboue) & L5 \\
\hline
\end{tabular}

\subsection{Mineralogical Characterization}

The mineralogical characterization was carried out by $\mathrm{X}$ ray powder diffraction (XRD). XRD using a PW1840 diffracto meter with $\mathrm{Cu} \mathrm{K \alpha}$ radiation operating at $30 \mathrm{~mA}$ and $40 \mathrm{kV}$.

The analysis was done in the continuous scanning mode with speed of $0,05^{\circ}$ per s within the range of $10^{\circ} \leq 2 \theta \leq 70^{\circ}$. The diffractometer is linked to a computer equipped with APD software. For data processing we used X Pert High Score software.

\subsubsection{Sewage Sludge Ash}

The diffractogram of the sewage sludge ash shows the existence of a complex polyphasic material composed of several crystalline phases and a glass phase [1, 22-23]. Besides glass, the main minerals identified are quartz $\left(\mathrm{SiO}_{2}\right)$, anhydrite $\left(\mathrm{CaSO}_{4}\right)$, phosphorus calcium silicate $\left(\mathrm{Ca}_{2} \mathrm{SiO}_{4}-\mathrm{Ca}_{3}\right.$ $\left.\left(\mathrm{PO}_{4}\right)_{2}\right)$ and minor phases (Figure 3).

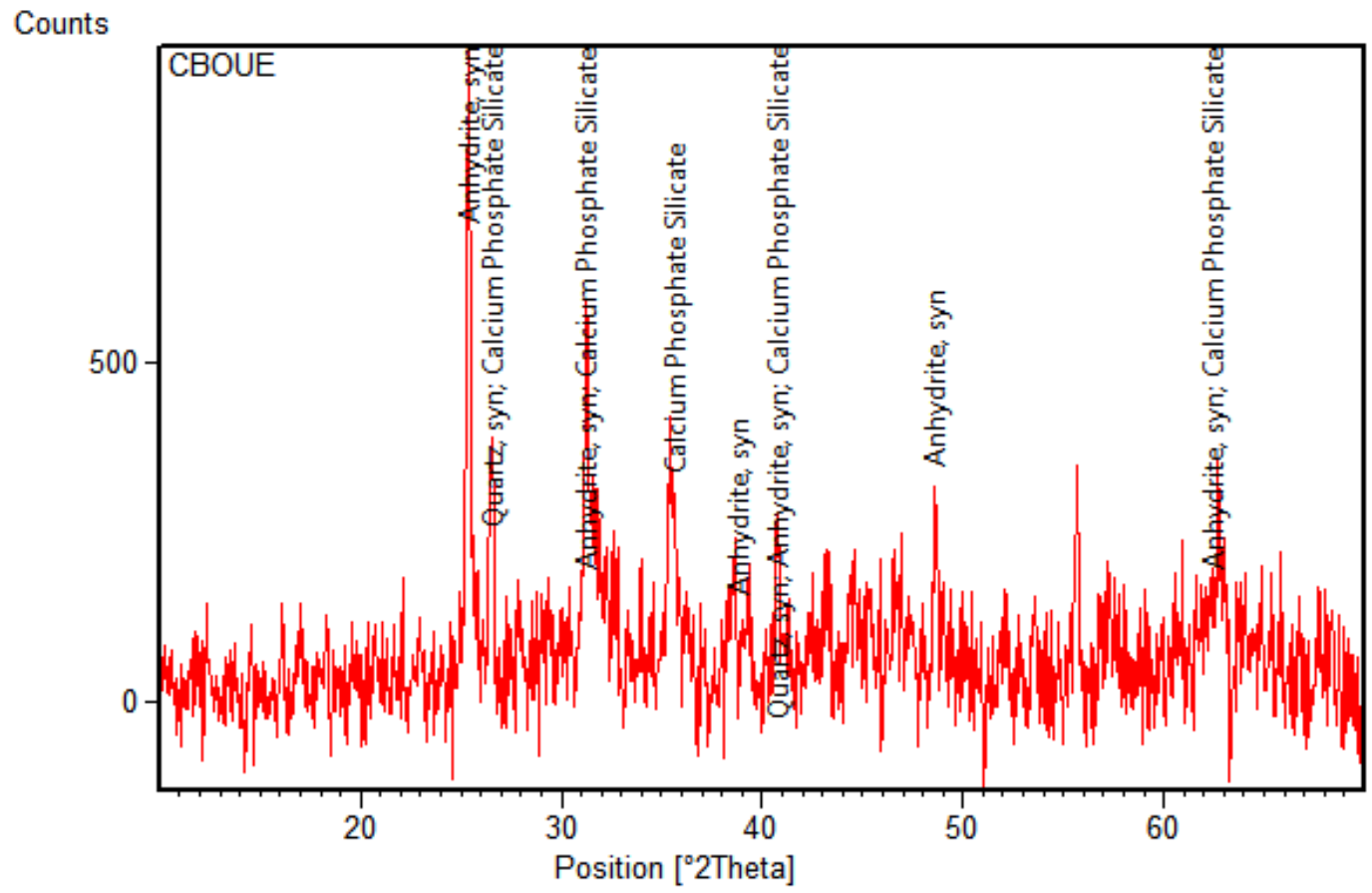

Figure 3. Diffractogram of the sewagesludgeash Thus the crystallinity of the sewage sludge ash is weak.

This weakness manifests itself in two aspects: The first is the high background and the second is that the intensity of the peaks is low [24].

This high background is due to the amorphous phase [25]. Silicium in the amorphous phase can react with lime and produce new phases.

\subsubsection{Lime}

Figure 4 shows the diffractogram of lime. The phases identified in lime are portlandite and calcite. Portlandite comes from the slaking of lime. The appearance of calcite could be due to the carbonation of porlandite exposed to air. 


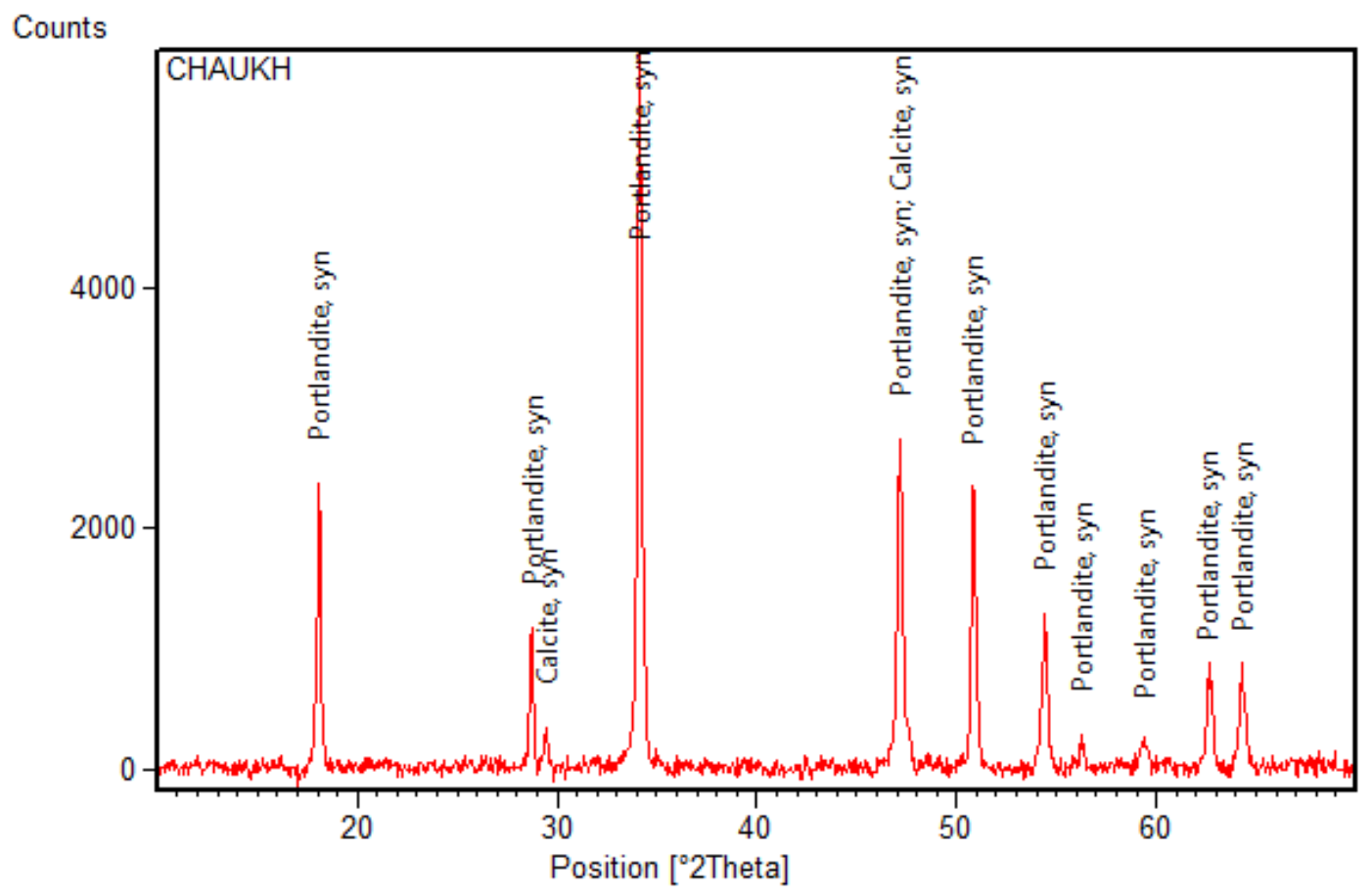

Figure 4. Diffractogram of lime.

\subsubsection{Mixtures}

We have made several formulations to assess the reactivity of ash by mixing it with lime. A fraction of the ash is rapidly soluble (sulfates, aluminum and silica) and can create newformed products in presence of lime [6].

This is because the lime released during hydration can react with the silicates and aluminates of the binder as in the case of cement. We have built mortars of different formulations to study evolution of compressive strength with respect to time and then to see how the compressive strength evolves at different times. After crushing these mortars, we analyzed the obtained powders by XRD which revealed the presence of new phases (Ettringite, Gehlenite, Calcium Silicate Hydrate) for certain formulations.

We have represented the diffractograms of $\mathrm{L}_{5}$ at different timescales: 3 days (L53JCB), 7 days (L57JCB) and 28 days (L528JCB) in Figures 5 to 7.

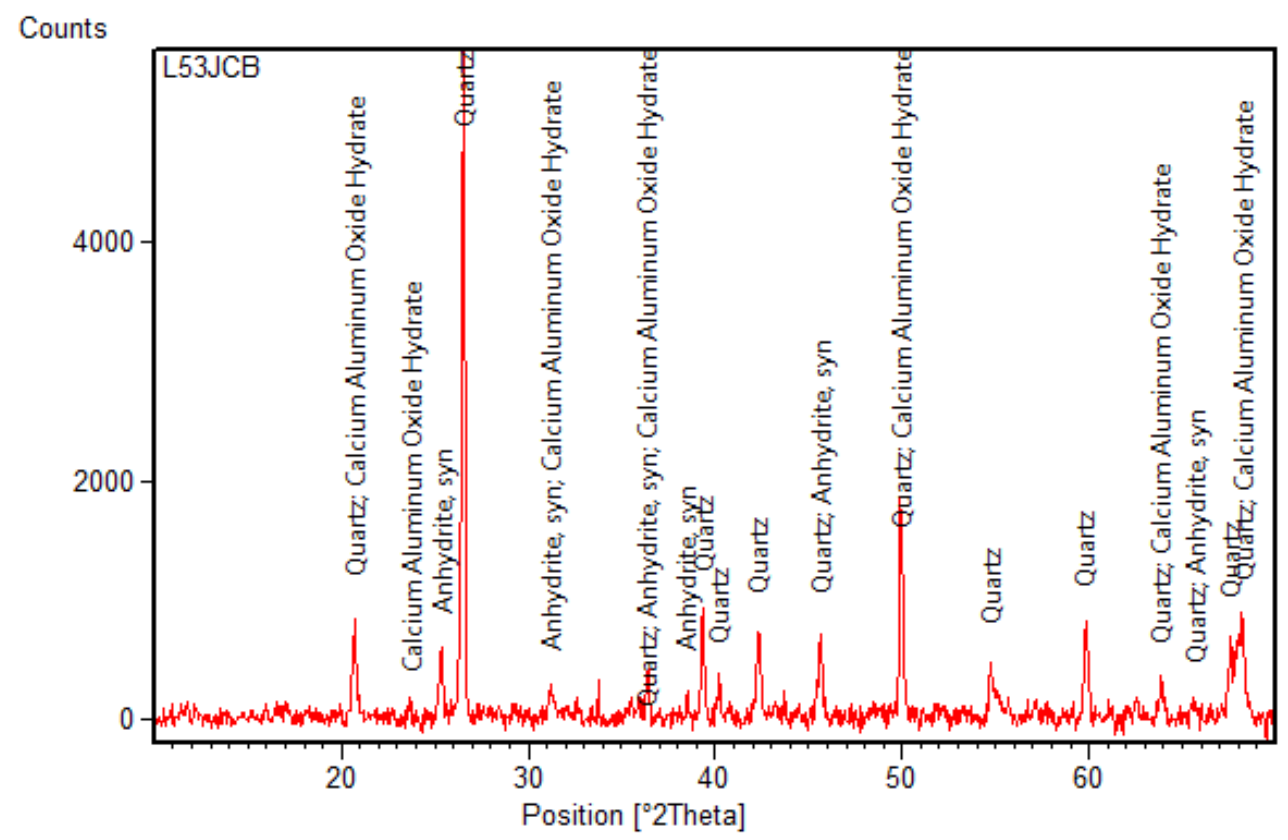

Figure 5. Diffractogram of L53JCB. 


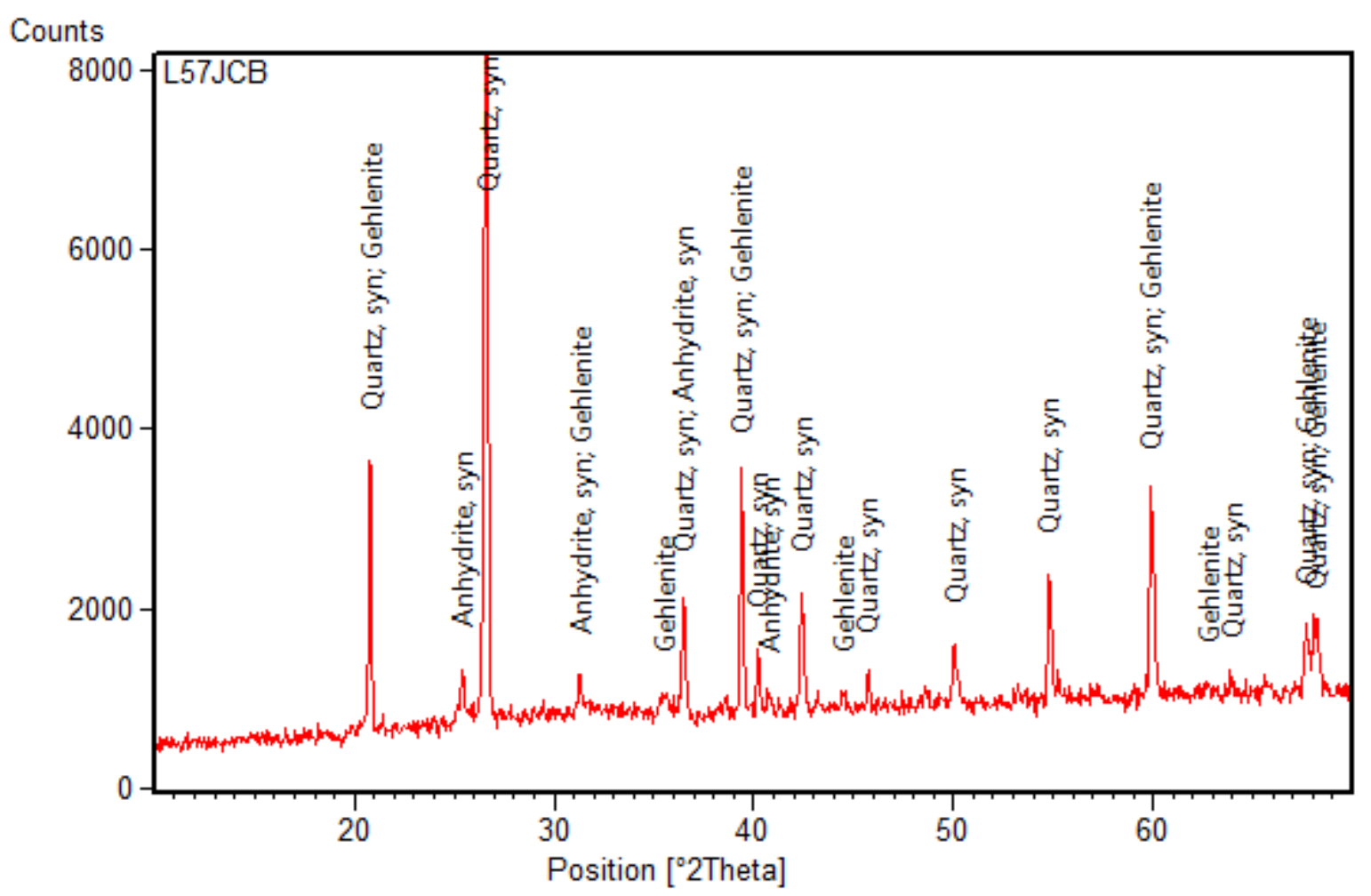

Figure 6. Diffractogram of L57JCB.

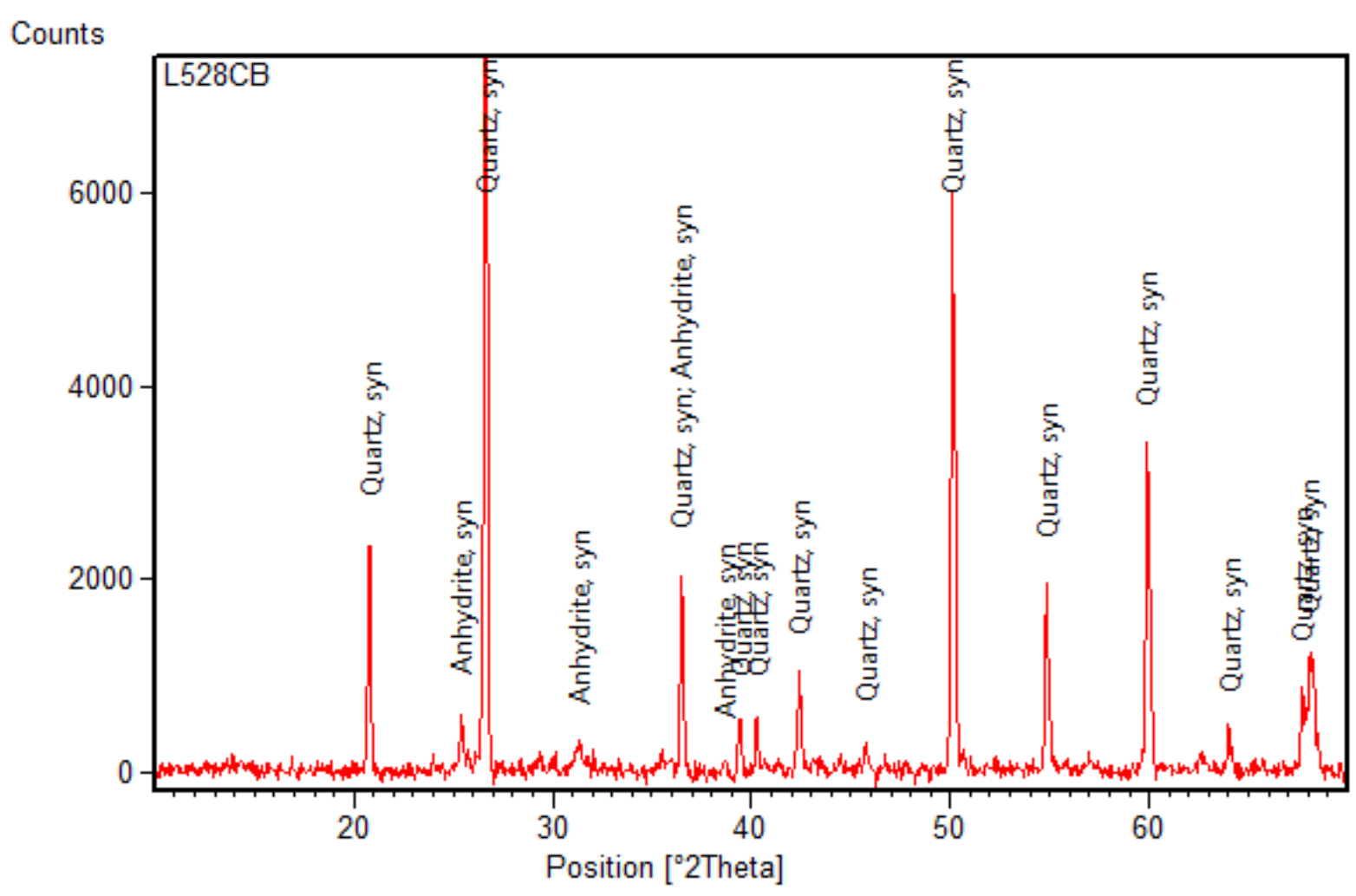

Figure 7. Diffractogram of L528JCB.

We find practically the same phases as those observed for the sewage sludge ash. This shows that ash alone hydrated has no reactivity under water. In addition, no hardening is not observed so we can say that the ash has no hydraulic character [6].

We present the diffractograms of the $\mathrm{L}_{4}$ binder at different time frames ( 3 days, 7 days, 28 days) at the level of Figures 8 to 11 . 
Counts

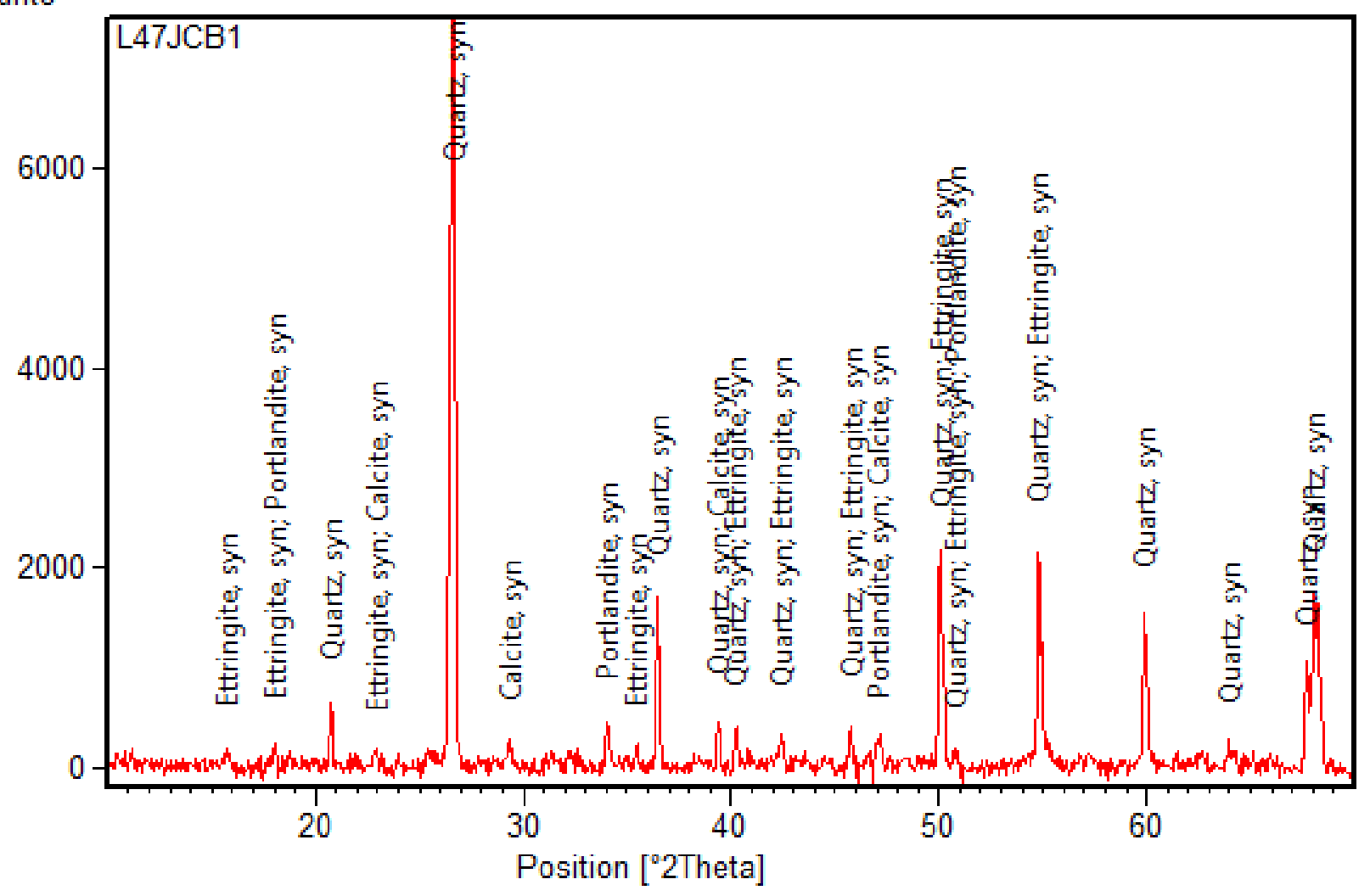

Figure 8. Diffractogram of L43JCB.

Counts

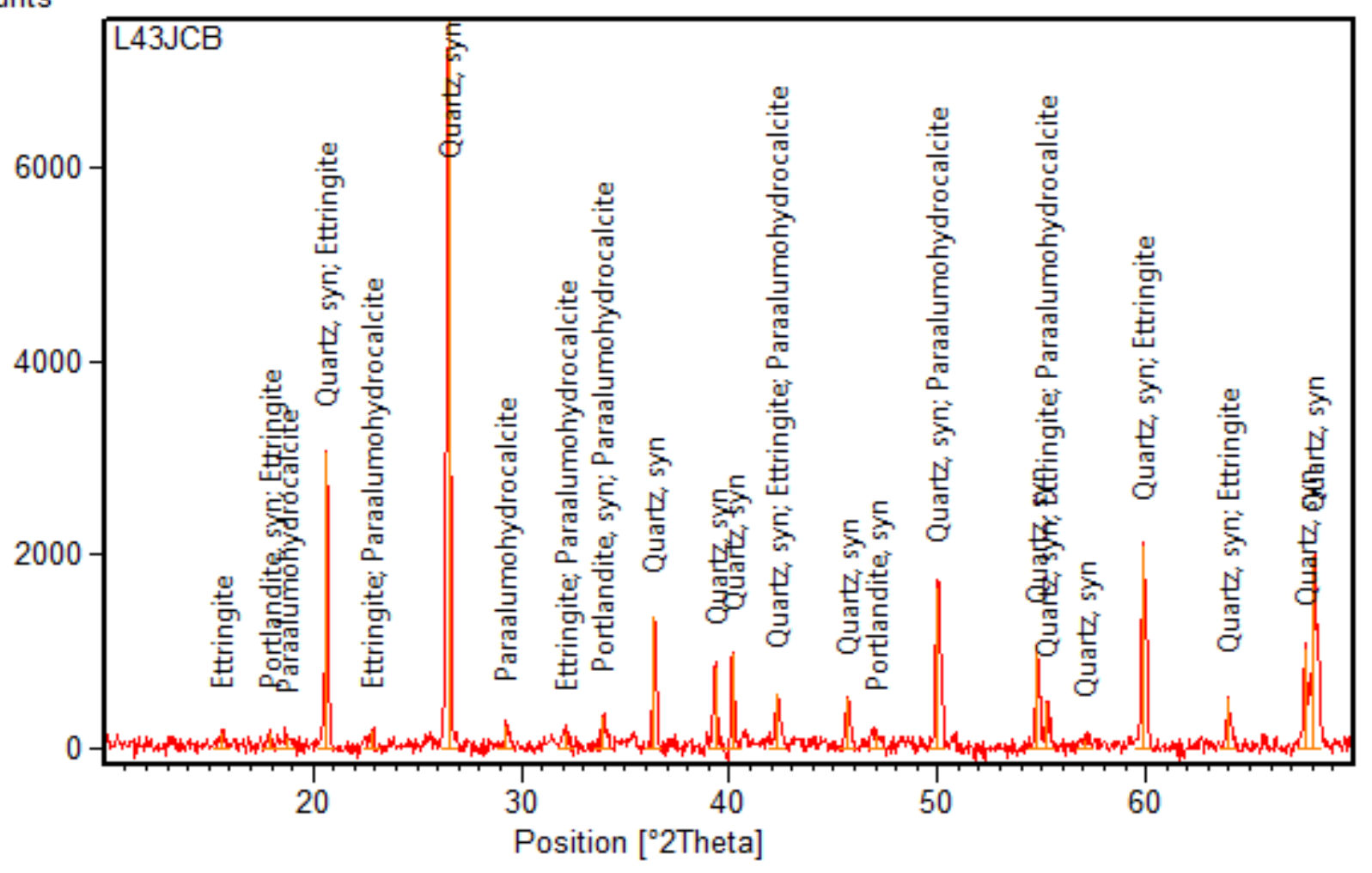

Figure 9. Diffractogram of L47JCB. 


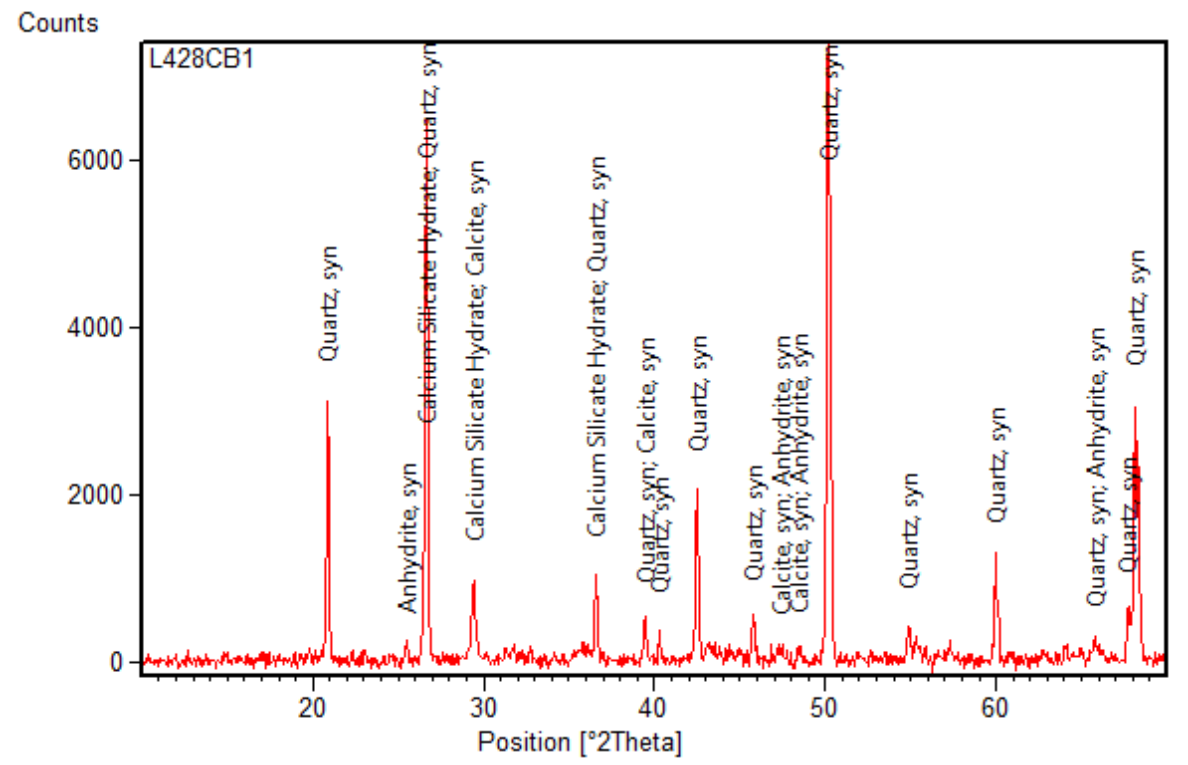

Figure 10. Diffractogram of L428JCB.

The $\mathrm{CaCO}_{3}$ that was detected in the $\mathrm{L}_{4}$ binder after hydration at 3 and 7 days comes from the carbonation $\left(\mathrm{CO}_{2}\right.$ uptake) of calcium hydroxide. This formation of $\mathrm{CaCO}_{3}$ does not produce new phases of hydration, but changes the speed of the hydration [26-27]. Part of the $\mathrm{Ca}(\mathrm{OH})_{2}$ portlandite formed is due to the hydration reactions of binder.

Gypsum, a hydrated anhydrite isa mineral added in the

$$
2 \mathrm{Al}^{3+}+3 \mathrm{SO}^{2-}{ }_{4}+6 \mathrm{Ca}^{2+}+32 \mathrm{H}_{2} \mathrm{O} \rightarrow \mathrm{Ca}_{6} \mathrm{Al}_{2}\left(\mathrm{SO}_{4}\right)_{3}(\mathrm{OH})_{12} ; 26 \mathrm{H}_{2} \mathrm{O}
$$

The presence of gypsum in the ashes is beneficial because it no longer needs to be added to form a binder based on ash and lime.

We distinguish in the binder $\mathrm{L}_{4}$ the gradual appearance of hydrated calcium silicate $\mathrm{CSH}$ at 28 days responsible for the resistance of cementitious materials.

In addition to the formation of ettringite, we also distinguish the appearance of aluminates and hydrated calcium carboaluminates, as well as hydrated gehlenite, after progressive disappearance of lime, therefore these phases clinker to regulate the setting of Porltand cement. In our binders, the gypsum peak observed in the binder has disappeared in favor of ettringite. In fact, it reacts with calcium aluminates in order to regulate the setting by forming ettringite $\left(\mathrm{Ca}_{6} \mathrm{Al}_{2}\left(\mathrm{SO}_{4}\right)_{3}(\mathrm{OH})_{12} ; 26 \mathrm{H}_{2} \mathrm{O}\right)$ in the following equation: evolve over time (3, 7 and 28 days).

The other mineral phases that have appeared come from the hydrating reactions of the silicates, aluminates and their combinations.

\subsection{Mechanical Behavior}

We have shown the compressive strengths of mortars made with different binders Figure 11.

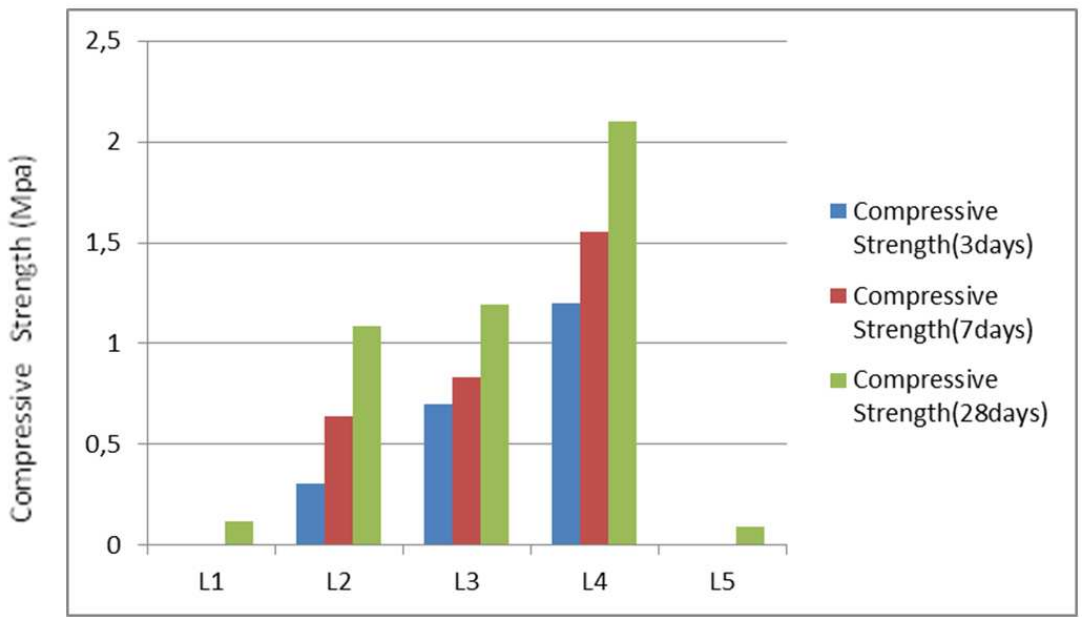

Figure 11. Evolution of the compressive strength as a function of the ash percentages and the age of the mortars. 
Overall, the compressive strength increases over time. That at 28 days is more important than that of 7 days itself more important than that of 3 days. The reactions within the binders therefore continue.

The binder $\mathrm{L}_{4}$ has a compressive strength greater than 1 $\mathrm{MPa}$ at $3 \mathrm{~d}$ and at $7 \mathrm{~d}$, the values are respectively $1.2 \mathrm{MPa}$ and 1.6 MPa. At 28 days its compressive strength is $2.2 \mathrm{MPa}$. Likewise, its compressive strength at 3 days is higher than that of $\mathrm{L}_{2}$ and $\mathrm{L}_{3}$ at 28 days. This shows that the $\mathrm{L}_{4}$ binder gives the best compressive strength whatever the age.

From the analysis of the diffraction results of the different formulations, we observed that ettringite can only form on sample $\mathrm{L}_{4}$, therefore its formation contributes to the increase in compressive strength of this binder.

This ettringite formation is explained by the equation (1) [1]. In addition to the formation of ettringite, a distinction is also made between the appearance of hydrated calcium aluminates and carboaluminates, as well as hydrated gehlenite, after gradual disappearance of the lime according to the formulation used.

The hydration reaction allowing the passage of the binder paste from the liquid state to the solid state.

It is a complex process in which the main binder compounds react to form new insoluble compounds which cause the material to set and gradually harden. The hydration mechanisms occur simultaneously but to better support our study we will study them separately.

Hydration aluminates

With $100 \%$ ash $\left(\mathrm{L}_{5}\right)$ no resistance is observed because the hydration of the ash alone has not given a new phase that participates in compression resistance. Thus the ash alone does not have a hydraulic character.

When the percentage of ash is low, the amount of silica, alumina and gypse is not sufficient to react with calcium hydroxide. This is the origin of the zero resistance observed for sample L1.

As the percentage of ash increases, compression resistance increases, which shows that there are new phases formed that are responsible for the strength of the lilibys $\mathrm{L}_{2}, \mathrm{~L}_{3}$ and $\mathrm{L}_{4}$ binders of the material.

The reactions of aluminates can take place in several stages:

Step 1:

The aluminates reactwith the sulphate in the gypsum to form ettringite (AFt phase) (hydrated calcium trisulfoaluminate): $\left.\left((\mathrm{CaO})_{6}\left(\mathrm{Al}_{2} \mathrm{O}_{3}\right)\left(\mathrm{SO}_{3}\right)_{3}, 32 \mathrm{H}_{2} \mathrm{O}\right)\right)$ [6]. This reaction is strongly exothermic. A layer of hydrates surrounds the aluminates which then form a protective layer around the grain. Thus these results show there activity of the ash in the presence of lime, which mechanically results the hardening of the paste.

Mineralogical analysis shows a significant consumption of lime, a decrease or disappearance of certain phases of the rawash and reveals new-formed phases.

Step 2: Transformation of ettringite into hydrated calcium monosulfate
When the gypsum is used up, the sulphate concentration in the solution drops. The ettringite then be comes unstable and dissolves to form hydrated calcium monosulfate (called AFm): $\quad\left(\begin{array}{lllll}(\mathrm{CaO})_{3} & \left(\mathrm{Al}_{2} \mathrm{O}_{3}\right) & \left(\mathrm{CaSO}_{4}\right), & \left.12 \mathrm{H}_{2} \mathrm{O}\right) . \quad \text { Chemical }\end{array}\right.$ reactions intensify.

Step 3: Hydration of residual aluminates

After a few weeks, the ettringite usually becomes unstable and dissolves to form hydrated calcium monosulfate (calledAFm): $\left((\mathrm{CaO})_{3}\left(\mathrm{Al}_{2} \mathrm{O}_{3}\right)\left(\mathrm{CaSO}_{4}\right), 12 \mathrm{H}_{2} \mathrm{O}\right)$ [28]. After a month, reactions proceed slowly with aluminate $\left(\mathrm{C}_{3} \mathrm{~A}\right)$ and aluminoferrite $\left(\mathrm{C}_{4} \mathrm{AF}\right)$ to form hydrated calcium aluminoferrite. Aluminum ferrite Tetracalcium $\left(\mathrm{C}_{4} \mathrm{AF}\right)$ is significantly slower to react and does not appear significantly until the gypsum is completely depleted.

Hydration of silicates

In contact with water, tricalcium silicates $\left(\mathrm{Ca}_{3} \mathrm{SiO}_{5}\right)$ and dicalcium silicates $\left(\mathrm{Ca}_{2} \mathrm{SiO}_{4}\right)$ dissolve in the form of ions. These interact with each other and form hydrated calcium silicates $(\mathrm{C}-\mathrm{S}-\mathrm{H})$ and portlandite $\left(\mathrm{Ca}(\mathrm{OH})_{2}\right)$. These reactions give off a lot of heat, so they are exothermic and can act as a catalyst for the hydration reaction. In the case of $\mathrm{C}_{2} \mathrm{~S}$, the hydration kinetics are slower and so is the amount of Portlandite formed. The strength of a binder is due to the entanglement of the C-S-H gel. In fact, the C-S-H develop on the surface of the grains of the non-hydrated binder and gradually fill in the capillary interstices between the grains. This slows down, after a few hours, the diffusion of ions and water to the anhydrous components of the system. In our binder, a small amount of hydrated calcium silicate was observed on the binder $\mathrm{L}_{4}$ at 28 days. This weakness could be due to the non-presence of these silicates in our ashes [29].

\subsection{Setting Time}

The setting start time measured with the Vicat apparatus is $5 \mathrm{~h} 30 \mathrm{~min}$ while for cement it is of the order of $2 \mathrm{~h}$. There is therefore a delay in setting the binder which can be attributed to the presence of phosphorus and the non-negligible Zinc content because these elements are known as powerful cement retarders [30].

The presence of gypsum in the ashes can also explain this delay in setting. In addition, the lime has a very slow start of setting which is 10 hours.

\subsection{Thermophysical Properties}

The results on thermal tests allowed us to obtain the thermal conductivity and effusivity of binder:

\section{Thermal conductivity $(\lambda)$}

The thermal conductivity reflects the ability of a material to transmit heat by conduction. The test gave an average thermal conductivity $(\lambda)$ of $0.33 \mathrm{~W} / \mathrm{m} .{ }^{\circ} \mathrm{K}$ for binder $\mathrm{L}_{4}$.

For a cement mortar: $\lambda=1.4 \mathrm{~W} / \mathrm{m} .{ }^{\circ} \mathrm{K}$ [31].

Thermal effusivity (E)

It indicates the capacity of materials to absorb (or restore) more or less quickly heat up.

The test results gave an average thermal effusivity of 
$639.0356 \mathrm{~J} / \mathrm{m}^{2}$.s. ${ }^{\circ} \mathrm{K}$ for our mortar.

For a cement mortar, the effusivity is: $\mathrm{E}=1754.99 \mathrm{~J} / \mathrm{m}^{2}$ S. ${ }^{\circ} \mathrm{K}$
The values of the thermal characteristics of some mortars are given in Table 5 .

Table 5. Comparison of thermophysical properties.

\begin{tabular}{lll}
\hline Mortar & Average thermal conductivity (W/m. $\left.{ }^{\circ} \mathbf{K}\right)$ & Average thermal effusivity $\left(\mathbf{J} / \mathbf{m}^{\mathbf{2}}\right.$.S. $\left.{ }^{\circ} \mathbf{K}\right)$ \\
\hline Based on lime and ash (Present work) & 0,33 & 680,05 \\
Cement based mortar [31] & 1,40 & 1754,99 \\
Clay-based mortar [32] & 0,35 & 705 \\
\hline
\end{tabular}

We find that the thermal conductivity of mortar made from ash and lime is lower than that of mortars made from cement on the one hand and clay on the other. This shows that ash and lime mortar is more resistant to conduction heat transfert hancement and clay mortars.

Also, the thermal effusivity value of lime and ash mortar is lower than that of cement and clay mortar. Thus, lime and ash-based mortar absorbs heat less quickly than cement and clay mortars. This mortar when used in the construction industry will develop better thermal characteristics than the latter two.

\section{Conclusion}

This paper aimed to improve our knowledge of the characteristics of SSA and its effect on the properties of lime based materials.

This allowed us to see that the chemical composition of sludge ash is similar to that of cement.

The main phases identified on lime are portlandite and calcite.

In the ash we identified quartz $\left(\mathrm{SiO}_{2}\right)$, anhydrite $\left(\mathrm{CaSO}_{4}\right)$, phosphate calcium silicate $\left(\mathrm{Ca}_{2} \mathrm{SiO}_{4}-\mathrm{Ca}_{3}\left(\mathrm{PO}_{4}\right)_{2}\right)$ and minor phases.

The ash alone mixed with water has not developed mechanical strength so it has no hydraulic character.

When they are mixed with lime in well-determined proportions to form binders, compressive strengths have been observed.

Binder $\mathrm{L}_{4}$ formed from $80 \%$ ash and $20 \%$ lime gave the best compressive strength at $28 \mathrm{~d}$.

The binder setting start time is greater than that of cement but shorter than that of lime. This delay in setting is attributed to the presence of the elements phosphorus and zinc on the ashes as well as gypsum

The thermal conductivity of mortar made from ash and lime is lower than that of mortars made from cement and clay. This shows that the ash and lime mortar is more resistant to heat transfer by conduction than the latter two.

Mortar made from ash and lime absorbs less heat than cement and clay mortars.

The binder has good thermal characteristics and could be used as a plaster or filler wall in the construction industry.

This material used in the construction industry will therefore present better thermal characteristics than cement or clay based materials.

As perspective, other basic knowledge about dimensional stability, water demand, leaching, morphology, nature of the bonds should be investigated. Use setting accelerators to reduce the observed set delay. Add plasticizers and additives to increase the compressive strength of the material.

\section{Conflicts of Interest}

There are no conflicts to declare.

\section{Acknowledgements}

We also acknowledge Laboratory of Civil Engineering Materials, High Polytechnic School, University of Cheikh Anta Diop, Dakar, Senegal for the technical assistance with the thermomechanical measurements, as well as Institute of Applied Nuclear Technology, Department of Physics, Faculty of Sciences and Techniques, University of Cheikh Anta Diop, Dakar, Senegal for helping with the XRF.

\section{References}

[1] M. Cyr, G. Klysz, S. Julien and P. Clastres, «Les cendres d'incinération de boues de stations de traitement des eaux polluées sont-elles utilisablesdans les matrices cimentaires? comparaison avec les cendres volantes de charbon,» revue francophone d'écologie industrielle, pp. 22-29, 2003.

[2] EUROSTAT, «http://epp.eurostat.cec.eu.int », 2005.

[3] S. Pan, D. Tseng, C. Lee and C. Lee, «Influence of the fineness of sewage sludge ash on the mortar properties,» Cement and Concrete Research, pp. 1749-1754, 2003.

[4] S. Badur and R. Chaudhary, ««Utilization of hazardous wastes and by-products as a green concrete material through $\mathrm{S} / \mathrm{S}$ process:» A review». Rev. Adv. Mater. Sci, Vols. \%1 sur \%217, pp. 42-61, 2008.

[5] W. Piasta and M. Lukawska, «The Effect of Sewage Sludge Ash on Properties of Cement Composites,» Procedia Engineering, pp. 1018-1024, 2016.

[6] M. Cyr, M. Coutand and P. and Clastres, «Technological and environmental behavior of sewage sludge ash (SSA) in cement-based materials.,» Cem. Concr. Res., pp. 1278-1289, 2007.

[7] S. Donatello et C. R. Cheeseman, «Recycling and recovery routes for incinerated sewage sludge ash (ISSA): A review,» Waste Management, p. 2328-2340, 2013.

[8] C. Lynn, R. Dhir, G. West and R. Ghataora, «Sewage sludge ash characteristics and potential for use in concret,» Conccrete and Building Materials, pp. 767-779, 2015. 
[9] J. Tay and K. Show, «Municipal wastewater sludge as cementitious and blended cement materials,» Cement and Concrete Composites., vol. 16, pp. 39-48, 1994.

[10] S. Pan, «Use of sewage sludge ash as fine aggregate and pozzolan in portland cement mortar,» Journal of Solid Waste Technology and Management, vol. 28, pp. 121-130, 2002.

[11] OECD, ««Organization for economic co-operation and development»,»: https://data.oecd.org/fr/, 2017.

[12] P. J. Potts, O. Williams-Thorpe and P. Webb, «The Bulk Analysis of Silicate Rocks by Portable X-Ray Fluorescence: Effect of Sample Mineralogy in Relation to the Size of the Excited Volume,» The Journal of Geostandards and Geoanalysis, pp. 29-41, 1997.

[13] M. Chen, D. Blanc, M. Gautier, J. Mehu and R. Gourdon, «Environmental and technical assessments of the potential utilization of sewagesludge ashes (SSAs) as secondary raw materials in construction,» Waste Management, pp. 1268$1275,2013$.

[14] R. Rajamma, R. Ball, L. Tarelho, G. Allen, J. Ferreira and V. Labrincha, "Characterisation and use of biomass fly ash in cement-based materials,» J Hazard Mater, pp. 1049-60, 2009.

[15] V. Somerset, L. Petrik, R. White, M. Klink, D. Key and E. Iwuoha, «The use of X-ray fluorescence (XRF) analysis in predicting the alkaline hydrothermal conversion of fly ash precipitates into zeolites,» Talanta, pp. 109-114, 2004.

[16] H. Bal, Y. Jannot, N. Quenette and A. Chenu, «Water content dependence of the porosity, density and thermal capacity of laterite based bricks with millet waste additive.,» Construction and Buildings Materials., p. 144-150, 2012.

[17] Y. Jannot, V. Felix and A. Degiovanni, «A centered hot plate method for measurement of thermal properties of thin insulating materials.,» Measurement Science And Technology, p. $1-8,(2010)$.

[18] K. Neupane, «Fly ash and GGBFS based powder-activated geopolymer binders: Aviable sustainable alternative of portland cement in concrete industry,» Mechanics of Materials, vol. 103, pp. 110-122, 2016.

[19] M. Coo and T. Pheeraphan, «Effect of sand, fly ash and limestone powder on preplaced aggregate concrete mechanical properties and reinforced beam shear capacity,» Construction and Building Materials, vol. 120, p. 581-592, 2016.

[20] K. Turk, C. Kina and M. Bagdiken, «Use of binary and ternary cementitious blends of F-Class fly-ash and limestone powder to mitigate alkali-silica reaction risk,» Construction and Building Materials, vol. 151, p. 422-427, 2017.
[21] S. Chin, D. Ing, A. Kusbiantoro, Y. Wong and S. Ahmad, «Characterization of sewage sludge ASH (SSA) in cement mortar,» ARPN J. Eng. Appl. Sci, vol. 11, pp. 2242-2247, 2016.

[22] M. Sall, P. Gueye, A. Traore, S. Diouf, M. Sy, G. Bouchez, A. Wade, M. Sane, G. Dieye and D. Diop, «Assessment of Fine and Coarse Sewage Sludge Ashes forTheir Potential Use in Civil Engineering,» Journal of Civil, Construction and Environmental Engineering, vol. 5, n 14, pp. 99-106, 2020.

[23] M. Coutand, M. Cyr and P. Clastres, «Use of sewage sludge ash as mineral admixture in mortars,» Construction Materials, pp. 153-162, 2006.

[24] W. Xu, J. Xu, J. Liu, H. Li, B. Cao, X. Huang and G. Li, «The utilization of lime dried sludge as resource for producing cement,» Journal of Cleaner Production, pp. 286-293, 2014.

[25] N. H. Rodríguez, S. Ramírez, B. Varela, S. Donatello, M. Guillem, J. Puig, C. Fos, E. Flores and J. Larrotcha, «The effect of using thermally dried sewage sludge as an alternative fuel on Portland cement clinker production,» Journal of Cleaner Production, pp. 94-102, 2013.

[26] J. Xiao, C. Gou, Y. Yin and Y. Wang, «Effect of $\mathrm{CaCO} 3$ on hydration characteristics of C3A,» Journal of Central South university of Technology, pp. 918-923, 2010.

[27] T. Sato and J. Beaudoin, «Effect of nano-CaCO3 on hydration of cement containing supplementary cementitious materials,» Advances in Cement Research, vol. 23, n \%11, pp. 33-43, 2011.

[28] P. Garcés, M. Carrión, E. Alcocel, J. Payá, J. Monzó and M. Borrachero, «Mechanical and physical properties of cement blended with sewage sludge ash,» Waste Management 24952502, pp. 2495-2502, 2008.

[29] T. Dyer, R. Dhir and J. Haliday, «Hydration Chemistry of Sewage Sludge Ash Used as a Cement Component,» Journal of Materials in Civil Engineering, pp. 648-655, 2011.

[30] G. Arliguie, J. Ollivier and J. Grandet, «Etude de l'effet retardateur du zinc sur l'hydratation de la pate de ciment portland,» cement and concrete research., vol. 12, pp. 79-86, 1982.

[31] K. Marti, «Catalogue d'éléments de construction avec calcul de la valeur U,» Office fédéral de l'énergie, 2002.

[32] N. Laaroussi, A. Cherkia, M. Garoum, A. Khabbazi and A. Feiz, «Thermal Properties of a Sample Prepared Using Mixtures of Clay Bricks», Energy Procedia, p. 337-346, 2013. 